\title{
1994年フィリピン・ミンドロ地震津波災害に おける復興対策の長期的効果に関する研究
}

\author{
奥村 与志弘 1 ・原田 賢治 $2 \cdot$ Edison Gica $^{3}$ ・高橋 智幸 4 ・越村 俊一 5 \\ 鈴木 進吾 6 ・河田 惠昭7 \\ 1 (財) ひょうご震災記念 21 世紀研究機構人と防災未来センター主任研究員 \\ （三657-0073 兵庫県神戸市中央区脇浜海岸通1-5-2） \\ E-mail:okumuray@dri.ne.jp \\ 2埼玉大学大学院理工学研究科助教（テ338-8570 埼玉県さいたま市桜区下大久保255) \\ E-mail:haradak@mail.saitama-u.ac.jp \\ ${ }^{3}$ NOAA Center for Tsunami Research （ T98115 7600 Sand Point Way NE, Bldg 3 Seattle, WA, USA) \\ E-mail:edison.gica@noaa.gov \\ 4秋田大学工学資源学部准教授（ （T010-8502 秋田県秋田市手形学園町1-1) \\ E-mail:tomo@ce.akita-u.ac.jp \\ 5 東北大学大学院工学研究科准教授 （干980-8579 宮城県仙台市青葉区荒巻1-1-11-1104） \\ E-mail:koshimura@tsunami2.civil.tohoku.ac.jp \\ 6京都大学防災研究所助教 （T611-0011 京都府宇治市五力庄） \\ E-mail:shingo@drs.dpri.kyoto-u.ac.jp \\ 7 関西大学環境都市工学部教授（=564-8680 大阪府吹田市山手町3丁目3番35号) \\ E-mail:ykawata@ipcku.kansai-u.ac.jp
}

\begin{abstract}
本研究は，被災後の居住規制により移住を余儀なくされた被災者の生活再建や地域社会の復興状況、お よび、それらを支援する中央・地方政府などの活動の長期的効果の把握を目的として実施した1994年フィ リピン・ミンドロ地震津波災害による被害を受けた集落への現地調査の結果をまとめたものである。その 結果，「Food-for-Work」と呼ばれる住宅再建手法などが効果的に作用し，政府による移住地開発は一定の 成功を収めていることが分かった。ただし, さらに今後の動向には, 土地所有者証明書の早期の発行や家 庭をも巻き込んだ防災教育の継続が重要であることも分かった。
\end{abstract}

Key Words : Long-term effect, relocation, tsunami,disaster education

\section{1.はじめに}

1994年11月15日午前3時17分頃（現地時間），フィリ ピン国ミンドロ島北部沖で，マグニチュードMw7.1の地 震が発生した（図-1）。この地震により，オリエンタル ミンドロ州北部，バタンガス州南部およびベルデ海峡の 島々に $2 \mathrm{~m}$ を超える津波が来襲した。この災害による死 者・行方不明者は，オリエンタルミンドロ州北部に位置 するバコ (Baco) 町で41名, カラパン (Calapan) 市で17 名など計78名に達した.

地震後政府は，この津波により被災した地域への居住 規制を行った ${ }^{1)}$.この規制により移住を余儀なくされた 被災者は，政府やNGOなどの支援を受けながら，新た な場所で生活を再建寸ることになった。
2008年現在，地震発生から14年が経過しており，地震 後に生まれた子供など当時の記憶を持たない住民が増加 していることが予想される中，政府による復興施策も含
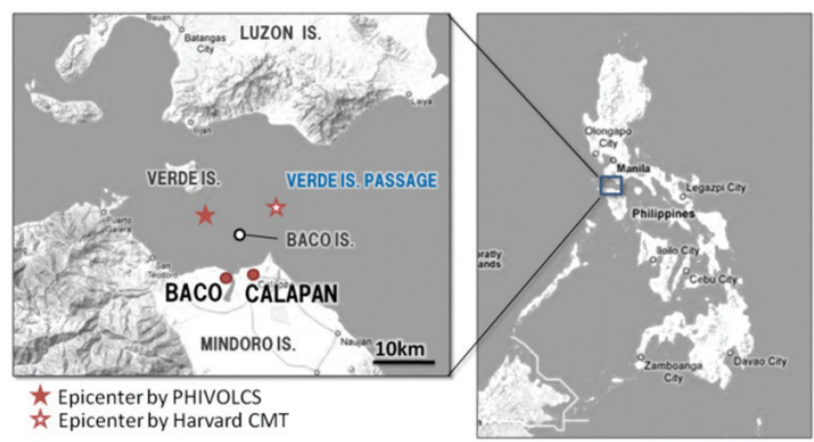

図-1 調査対象地域の位置関係（Google Mapに加筆）． 
めた当時の被災経験は，この地域にどのように根付いて いるのか，検証できる段階にある.

本報告は，被災者の生活再建や地域社会の復興状況， 労働者や観光客など地域住民でない人々に対する津波脆 弱性の現状，および，それらを支援した中央・地方政府 などの活動の長期的効果の把握を主目的として，発災か ら14年が経過した時点で実施した現地調査の結果をまと めたものである。調査は，2008年11月18日から22日まで の5日間，第2の犠牲を出したCalapan市におけるWawa Barangay（ワワ・バランガイ ; バランガイは同国におけ る最小行政単位，以下，Brgyと略記）と最大打ち上げ高 を記録したリゾート地開発中のBaco島を対象に，住民や 労働者への聞き取り調査と被災地および移住地の現地視 察を中心に実施した。 なお，本研究の調査対象地域であ るCalapan市におけるこの災害での死者は，全てWawabrgyの住民である.

\section{2. 被害の概要}

この災害では，全犠牲者のうちの約6割が津波による 犠牲者だったと考えられている ${ }^{2)}$. 津波は，バコ島南西 部で最大打ち上げ高さ $7 \mathrm{~m}$, ミンドロ島北東部沿岸やル ソン島南部でも津波打ち上げ高さ2〜 $4 \mathrm{~m}$ が観測された （津波来襲時の潮位からの值）。発災直後の調査によっ て得られている津波打ち上げ高さは図-2に示す通りであ $3^{13)}$. この津波は，マグニチュードMw7.1の横ずれ断層 の端付近で生じる地盤の隆起・沈降だけでは説明がつか ない津波高が来襲していたため，ベルデ島による造波板 作用も津波を発生させたとする解釈が提示されている13).

被害の特徴としては, 死者・行方不明者78名のうち大 半が子供であり，例えばCalapan市では17名のうちほぼ半 数が10歳以下の子供であった。 また，負傷者430名，全 壊家屋1430棟，部分破壊家屋6036棟，乙して，被災者の

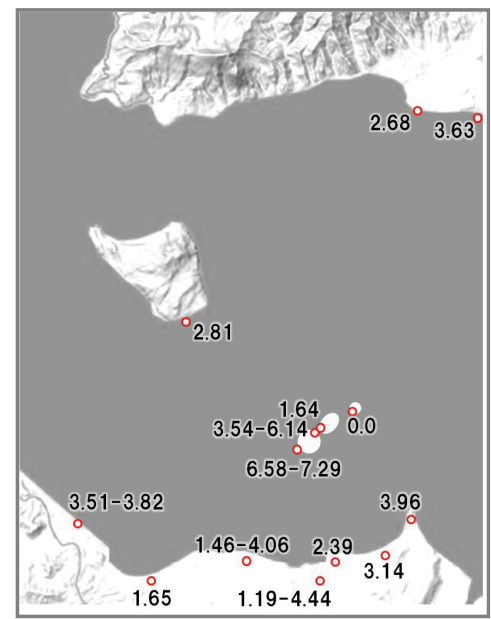

図-2 1994年ミンドロ津波の津波打ち上げ高さ（観測值）。
数は22452世帯にも達したとの記録が残されている2).

\section{3. 移住施策の概要}

居住規制がかけられた Wawa-brgy への現地調査の結果, 移住施策に関して，被災前には 1 つのバランガイで生活

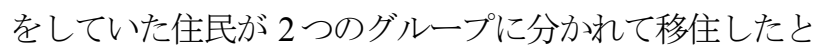
いう特徵が分かった．移住地の位置関係とグループの分 かれ方については以下の通りである. 一方は，元のバラ ンガイがあった場所より数十メートル内陸に位置する土 地で，本家（家督を継ぐ家族）を中心とする住民 85 世 帯が移住し，New Wawa-brgy として 1 つのバランガイを 組織していた．この呼称は，被災前のバランガイ (Old Wawa-brgy）と区別するために著者らが便宜的に用いて いるものである. 他方は, 元のバランガイがあった場所 から $1 \mathrm{~km}$ ほど離れた Mahal Na Pangalan-Brgy（マハル・ ナ・パンガラン・バランガイ）内の Ubasan（ウバサン） と呼ばれる土地で，分家を中心と寸る住民 36 世帯が移 住し，Mahal Na Pangalan-Brgy の住民として組み込まれる 形となった。各地域の位置関係を図-3 に示寸。なお上 記の事実は, New Wawaのバランガイ長と Ubasan の評議 員の証言に基づくものである. 彼らの詳細な情報は 5 章, 6章を参照されたい.

\section{4. 被災地OId Wawaの現在の状況}

被災から14年が経過した現在，被災地Old Wawa-brgyは， ブロック造の住宅や木造の倉庫, 豚小屋が数棟並んでい た（図-4）。本調査では，そのうちの一棟に住む女性

（図-5）から話を聞いた。1994年の津波発災時，彼女は 妊婦であったが，走って津波から逃げられたという，彼 女によると，居住規制に従わないと行政の支援が受けら

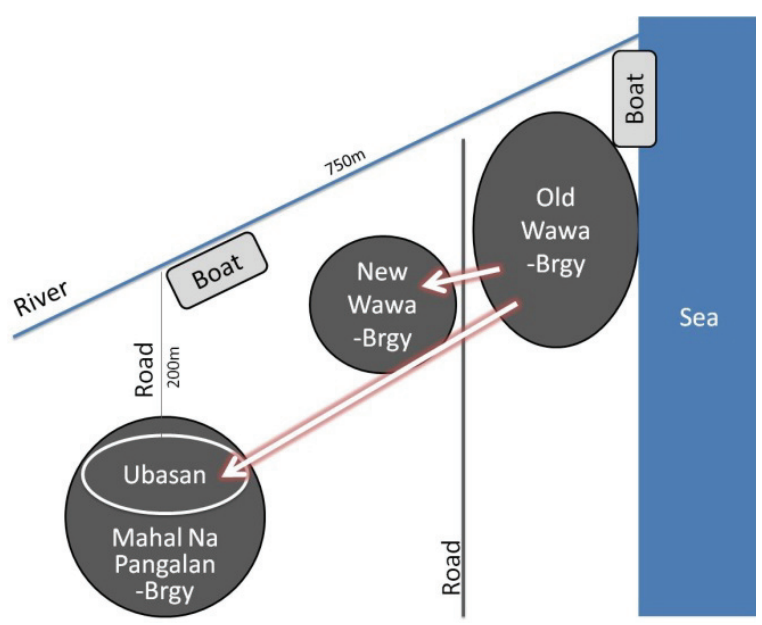

図-3 OldWawa，New Wawa，Ubasanの位置関係. 


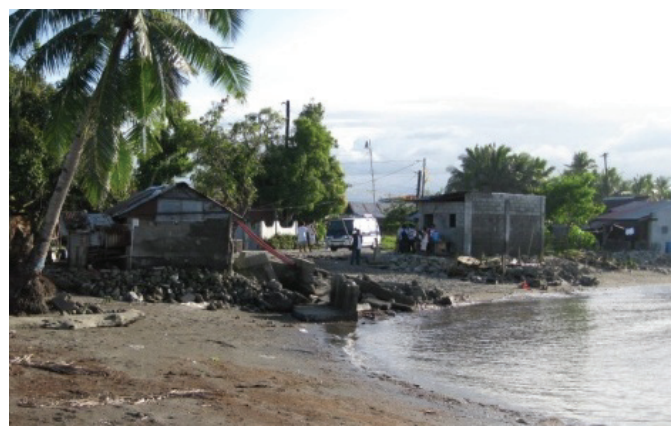

図-4 Old Wawaの町の様子（Wawa，2008年11月19日撮影）.

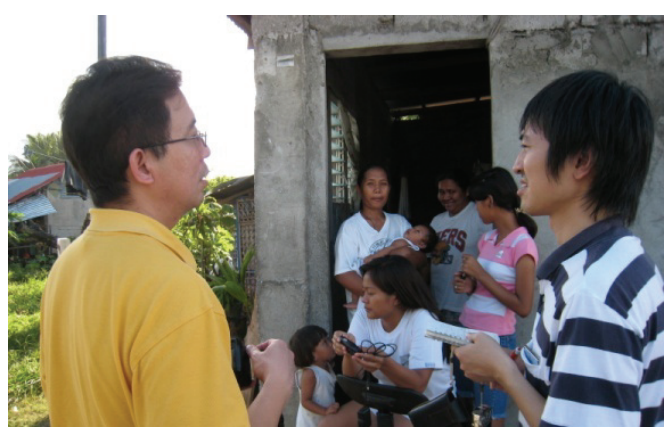

図-5

Old Wawaでのヒアリングの様子. 赤ん坊を抱く中央 の女性に話を聞いた（Wawa，2008年11月19日撮影）。

れないが，それでも銀行ローンを使い，住み慣れた場所 に自力で住宅を再建したという.

Ubasanの評議員によると，現在居住が禁止されている この土地に 20 世帯が生活している．内訳は，被災後移住 勧告に従わなかった2世帯と, 一度は勧告に従いNew Wawaへ移ったが，その後Old Wawaへ戻った18世帯とな っている. 因みに，移住勧告に従わなかった2世帯は何 れもWawaで身内を失った家族である．身内を失った家 族は他に4世帯あり，彼らは皆Ubasanで生活している.

将来の災害を念頭においた津波危険地域への居住規制 は，長期的に運用されて初めて効果を発揮するため，持 続性が重要である。しかし，現実は移住政策に従わない， 或いは一時的に従ったとしてもその後戻り住むといった 住民が一部に現れている．その一因として，この土地で の住宅再建を物理的に阻むものがなかったことが挙げら れる.この点については，1994年6月4日にインドネシア のジャワ東部で発生した津波により121名の犠牲者を出 したPancer村の事例との対比により考察が可能である.

Pancer村では被災後壊滅的な被害が出た海に面した土地 を居住禁止とし，その土地にヤシを植え，背後に復興住 宅を整備するという施策をとった，そのため，物理的に もとの被災した土地へ戻ることができないようになって おり，被災後14年を経た2008年3月時点でもヤシを植え た海に面した土地に戻り住む住民はいないことが確認さ れている4). 危険な土地として居住禁止にした土地を, 空き地としたのかヤシ林として整備したのかが居住規制 施策が長期的に効果を持つことに影響したと考えられ，

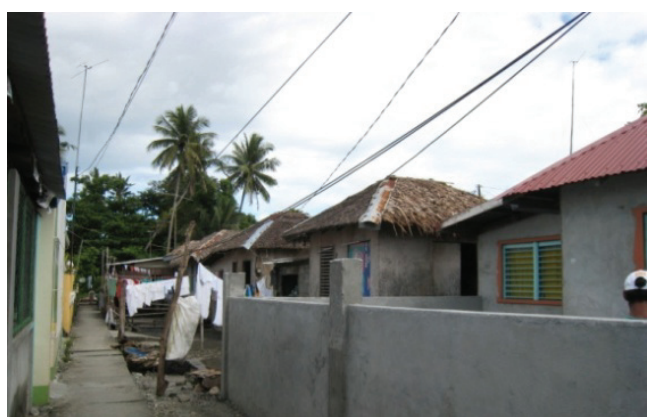

図-6 New Wawaにおける家屋の様子（Wawa，2008年11月 19日撮影）。

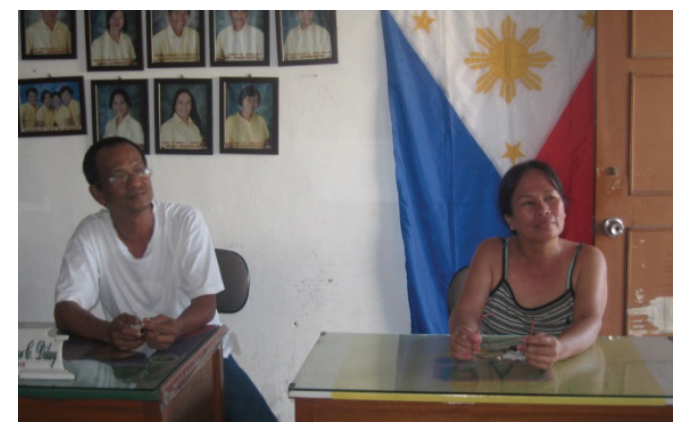

図-7 New Wawaでのヒアリングの様子. 左の人物がバラ ンガイ長（Wawa，2008年11月19日撮影）。

このことは教訓として今後の復興施策を考える上で考慮 すべき事項である.

また，当時津波から逃げ切れたという経験を持つ住民 が居住規制地域に戻り住んでいた。この事実は，実体験 から，津波は走って逃げれば助かるという災害イメージ の固定化が起こり，居住規制が守られなくなっている可 能性があることを示唆している. 災害イメージの固定化 を防ぐために正確な知識を身につける必要がある.

\section{5. 移住地New Wawaの現在の状況}

New Wawa-brgyは，私有地だったものをNGO（組織名 は未確認）が購入した土地であり, 被災後Old Wawaよ り85世帯が移住した．現在，部分的に舗装された道路沿 って，互いによく似たブロック造の復興家屋が整然と並 んでいた（図-6）。本章は，New Wawaのバランガイ長 （公選されるバランガイの最高責任者）の証言（図-7) に基づき, Ubasanの評議員による裏付けを得て記述した ものである.

本バランガイの家屋は, 被災者自身が被災後に建設し たものであるという。この地域において，家屋の再建を 支えたのは，家屋資材と当面の食糧を支給した政府の DSWD (Department of Social Welfare and Development ; 社会 福祉開発省）および1世帯あり $64 \mathrm{~m}^{2} の 土$ 土地を与えた前述 のNGOの支援である. 本移住地は, 現在約 100 世帯にま で人口が増加している，一方で，前章で述べた通り，18 
世帯がOldWawaに戻っている.

この移住地では，被災後「Food-for-Work」という生活 支援策の適用を受けた点が注目される。すなわち， DSWDが実施したこの「Food-for-Work」という枠組みは, 被災者に復興事業に関寸る仕事を与え，その対価に食糧 を支給するというもので，被災者自身が事業に参画する ことで，彼らに主体性をもたせる狙いがある（2006年レ イテ島大規模地滑り災害でもこの生活支援策「Food-forWork」は適用されたの)）。しかし，移住地における復興 家屋建設事業に対してこの生活支援策の枠組みを適用し た今回のケースは，この手法が被災者の定住を促してい る可能性があり，著者らはむしろその可能性に注目した。 それは著者らが，津波災害後に持続的に地域の脆弱性を 小さくするためには，津波危険地域に住まないように居 住規制を行うとともに，津波リスクの低い地域への定住 を促す施策も併せて実施することが肝要である，と考え ているからである.

被災から14年が経過した現在，被災者は復興家屋をそ れぞれにとって住みやすいようにリフォームするなどし て生活している. リフォームをするということは，その 住宅に住み続けることの意思表示と捉えることに無理は ないと思われる。「Food-for-Work」の枠組みによって, 復興住宅の建設に被災者自身が汗をかくことで，その住 宅に対して愛着がわき，こうした状況を作り出している と考えられる.

次に, 居住地と仕事場へのアクセスに着目した. 日々 の生活の不便さは，短期的には我慢できても長期的には その不便さを解消する方向へと作用する可能性がある.

結論から言うと，これは比較的良好な地理条件となって いる. New Wawaにおいて, このアクセス条件が重要で あると考えられる職業は全住民の過半数を占める漁師で ある．漁師を除く，家政婦や三輪自動車のドライバーな ぞにとっては，この条件の重要性は低いと思われる，漁 師は，移住地からボートを停泊させている場所まで徒歩 5分で行ける（図-3）。住民は，14年前の移住によって， やや内陸に移動し不便になったものの，それは大部分の 漁師にとって, Old Wawaに戻らせるほどの影響はなか ったと考えられる.この移住に伴う居住地と仕事場への アクセスの不便さについては, 日本の三陸地方の高地移 転の事例でも ${ }^{5}$ ，もとの低地に戻り住む要因の一つとし てあげられているが, New Wawaでは平地の河川近くの 内陸への移住であり, 道路や船着き場などの仕事や生活 をするために必要な社会インフラの整備が行われたため, 影響が少なかった．これらのように，移り住んだ先に定 住させるための復興施策（社会基盤整備）を行うことが, 移住施策を長期的に機能させる助けとなっていると考え られる。

\section{6. 移住地Ubasanの現在の状況}

Ubasanは， Mahal Na Pangalan-Brgy内のバナナ林だった 土地をキリスト教の牧師が被災者に寄付したものであり, 被災後36世帯が移住した。現在の状況は，New Wawabrgy類似しており，互いに似たブロック造の家屋が並 んでいたが，道路が全く舗装されていない点，庭に植物 が豊富に植えられている点は特徵的である（図-9）。本 章は, Ubasanのバランガイ・カガワッド (Barangay Kagawad）（バランガイの最高意思決定機関である評議 会をバランガイ長とともに構成する評議員であり, 定員 は 7 人. 住民による選挙によって選ばれる．）の証言に 基づいて記述したものである.

復興家屋建設の経緯は，New Wawa と同様DSWDの支 援の下，被災者が自ら建設をしたという（図-8）。ただ

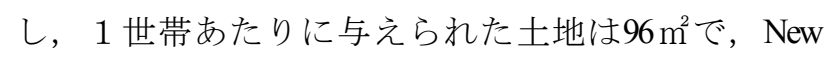
Wawaより $32 \mathrm{~m}^{2}$ も広い. 土地に余裕があることによって， 庭に植物が植えられるなどより快適な住環境を生み出せ ている，本移住地は，被災者でない世帯（8世帯）の移 住も合わせて, 現在72世帯にまで倍増している. Ubasan からOld Wawaに戻った被災者はいない.

まず, この移住地では, 既存のコミュニティとの関係 性に注目した. New Wawaのように被災者だけで $1 つ の$ コミュニティを組織するのではなく，既存のコミュニテ イに組み込まれる形での復興が行われた今回のようなケ 一スでは，長期的な復興を考える上で，既存のコミュニ ティとの良好な関係性を構築することが重要である.イ

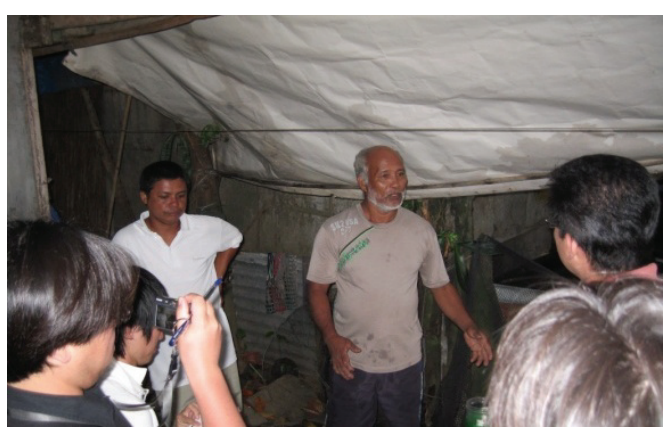

図-8 Ubasanでのヒアリングの样子. 中央の人物がカガワ ッド（Ubasan，2008年11月20日撮影）。

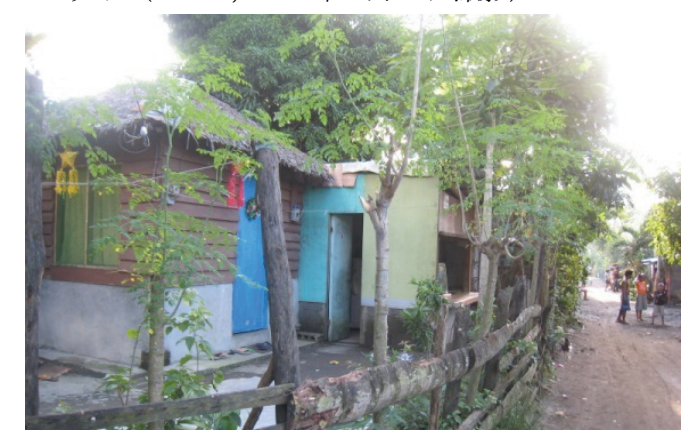

図-9 Ubasanにおける家屋の様子（Ubasan，2008年11月19日 撮影) . 
ンタビューに応えてくれたカガワッドによると，災害前 からあったMahal Na Pangalan-Brgyの住民と，Ubasanの住 民の関係は良好であるという。そその根拠として，元の住 民に影響のない，何もない土地に移住地が建設されたこ とを挙げていた. しかし，この地に後からきた被災者は， 比較的広い土地や家屋資材などの支援を受けており，当 該バランガイで以前から住んでいた住民よりも充実した 環境を享受している可能性もあり，こうした社会秩序の 変化から両者に軋轃が生じている可能性も考えられる.

こうした心理的影響については, 今後, 既存のコミュニ ティ側の住民に対するインタビューを実施するなどして, 調査し検証する必要がある.

次に, New Wawa之同様に, 居住地と仕事場へのアク セスに着目した．結論から言うと，本移住地に関しても， 比較的良好な地理条件となっている. Ubasanにおける生 業の状況は, New Wawaと同様で，このアクセス条件が 重要であると考えられる漁師が全住民の過半数以上を占 めており，その他には，家政婦やドライバー，大工など がいる. Ubasanからボートを停泊しているバルヤン

(Baruyan) 川の河川敷までは，約200mの距離である.

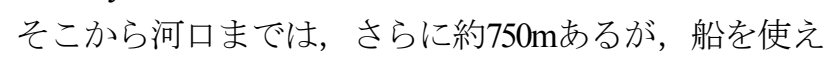
ばアクセスは良好であると言える（図-3）。New Wawa の漁師ほどのアクセスの良さはないが，1km以上離れる New Wawaの停泊地を利用するよりかは利便性の高いア クセスの方法をとっていることが分かった.

また, 被災後, 行政からUbasanの被災者に発行された という土地所有者証明書が注目される. 援助によって手 に入れた土地の所有権を行政から正式に得られることは, 被災者にとって，その土地に住み続けられることを公的 に保障されていることを意味する，そのため，少なから ずこの証明書によって, 被災者は安心して定住できるも のと考えられる. New Wawaでは，なぜかこの証明書が 未だ被災者の元に届いていない.このことは，18世帯が Old Wawaに戻ったNew Wawa と，1世帯も戻っていない Ubasanの違いの要因の一つになっている可能性がある. なぜこのような事態が生じているのか原因を明らかにす るとともに，Old Wawaへ戻る住民をこれ以上増やさな いためにNew Wawaの住民に対して証明書の発行を急が なければならない。

\section{7. 被災経験の伝承と防災教育}

被災から14年が経過し，津波災害を経験していない子 供たちの誕生や被苂地外からの住民の流入によって, 津 波を経験することでこの地域に生まれた文化や被災体験 そのものの継承が危惧される。 そこで, 被災経験の伝承
や被災後に実施されるようになった防災教育などの取組 について調査した. 本章は, 前章に続きUbasanの評議員 の証言に基づく.

Ubasanでは，1994年の津波災害を知らない，津波を経 験していない子供および被災地外からの住民に対し, 被 災者が当時の経験を伝えているという，結果として，何 割の住民が，当時の災害について，どの程度知っている のか, また，どのような機会に伝えているのかについて はより詳細な調査が必要である. そのような中, 当時の 被災経験を伝える機会となっているものとして, 高等学 校での防災教育がある.Calapan市では，94年の災害を契 機に，高校生を対象に避難のための教材を作成し避難訓 練を行っている (Evacuation Drill). Ubasanの高校生は, 学校でこの教材を使った防災教育を受けている. この教 材は, 地震を対象とした避難訓練を実施するためのもの であるが，学んだことを家庭で共有することまで明記さ れている点は興味深い. 子供への教育を地域全体に波及 させる効果を期待できる取組として評価される.

こうした防災教育は, 継続的に実施されることが重要 である.「フィリピンでは, 行政のトップが代わると, 計画が代わってしまい, 長期的な取り組みが困難だ （JCA野村氏，山本氏）」とする見方がある中, 地方自 治体が作成した教材を自治体が使うのではなく, 政治的 な動向に左右されにくい高校に配布し，学習させること で，この教材は防災教育を長期的に実施できる社会的な 枠組みの中で活用されているといえる.

防災教育などの防災対策は，地域への長期的な効果を 十分に考慮して，実施される必要がある，例えば，津波 危険地域一の居住規制に関しても，実際にこの対策が効 果を発揮するのは, 直後ではなく, 数十年や数百年後の 次の津波来襲時であることを忘れてはいけない，その時 まで，この規制が守られていなければ，何の意味もなさ ないといっても過言ではない.

\section{Baco島の現在の状況}

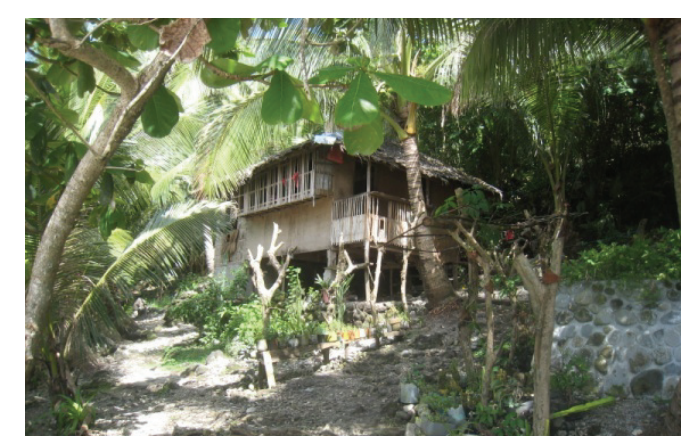

図-10 Baco島の作業小屋の様子（Baco島，2008年11月20 日撮影）。 




図-11 Baco島でのヒアリングの様子. 左の男性労働者の話 を聞いた（Baco島，2008年11月20日撮影）。

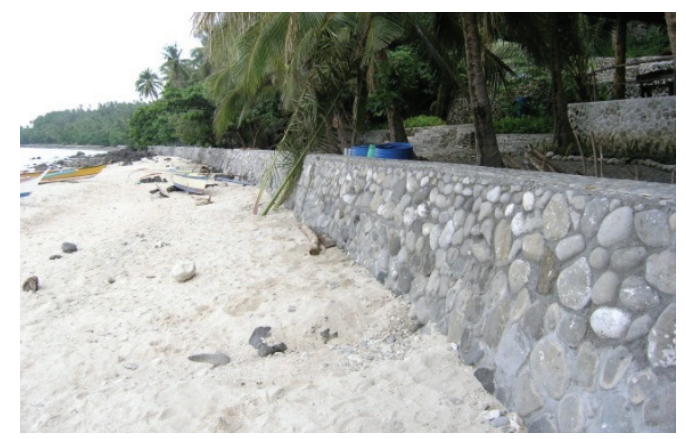

図-12 Baco島の防潮堤（Baco島，2008年11月20日撮影）.

Calapan市の北西に位置するバコ（Baco）島は，現在リ ゾート地開発のために住み込みで働いている労働者たち が生活をしている小島である（図-10）。津波災害のあ った94年当時も，この島で生活をしていたのはBaco町民 やCalapan市民ではなく, 現在とはまた別の労働者であっ た. ただし，雇用主はこの島の所有者で，現在と同じで ある.この島は，94年の津波災害では，南部で最大打ち 上げ高7.29mを記録し，2名が死亡している。この地域は, 生活をしている人々が被災地の市民ではないという特殊 性を有しており，本調査では，被災した本地域のリゾー 卜地開発の再開や労働者の安全性，および，リゾート地 完成後の観光客の安全性について検討するため，建設作
業を行っている労働者に対するヒアリング調査と現地視 察を行った．本章における労働者の証言は，被災後マニ ラからBaco島に家族で移り住んできたという図-11の男 性労働者のものである.

まず，被災前後の労働者間で津波災害の経験が伝えら れていた点が注目される. 被災前の労働者は，例外なく この地に残っていない．仲間に死者を出すほどの被害を 受け，被災後も継続して働く意思を持つものはいなかっ たものと考えられる，そこで雇用主は，被災後，新たに 首都マニラで労働者を雇用し，Baco島でリゾート地開発 に従事させている，そのため，94年の津波災害以降にこ の島にやってきた労働者は，津波を経験していない，し かし，彼らは当時の津波災害で，島のどこまで津波が来 襲したか，どの程度の被害が出たのかなどといった知識 を持っていた。 これには, 雇用主が被災前後の労働者間 で情報交換をする場を用意したという背景があった．目 的は定かでないが，（1）仕事の引き継ぎのため,

新たに雇用した労働者の安全性を確保するためなどが考 えられる，とはいえ，結果として，94年の津波に関する 経験が伝わっている事実は, 現在雇用されている労働者 の安全性と津波に強いリゾート地建設の観点から極めて 重要であると考えられる.

次に，被災後に新たに建設された防潮堤が注目される （図-12）。94年の津波の高さを基準に考えると決して 十分な高さではないが，雇用主がリゾート地の利用者の 安全性を考慮した可能性がある. 今後, リゾート地が完 成し観光客が訪れるようになった時，どれだけ災害に対 する安全性が確保されるか現状では不透明だが，リゾー 卜地の開発者の責任はもちろん, 住民でない観光客の安 全性に対するBaco町やCalapan市の対応に関しても今後注 目していかなければならない.

最後に，1994年に被災した労働者に対する行政支援に ついて触れておきたい，確認はできていないが，彼らは

\begin{tabular}{|l|}
\hline 物理的要因 \\
・従来の土地におけるスペース \\
住環境的要因 \\
・彷来の土地におけるインフラ整備 \\
経済的要因 \\
・住宅建設コスト \\
仕事 \\
\hline
\end{tabular}

\begin{tabular}{|l|}
\hline 心理的要因 \\
災害観 \\
・個別の被災経験 \\
しごと \\
\hline 居住地と仕事場へのアクセス \\
すまう \\
・移住先のコミュニティとの関係性 \\
・土地所有権 \\
\hline
\end{tabular}

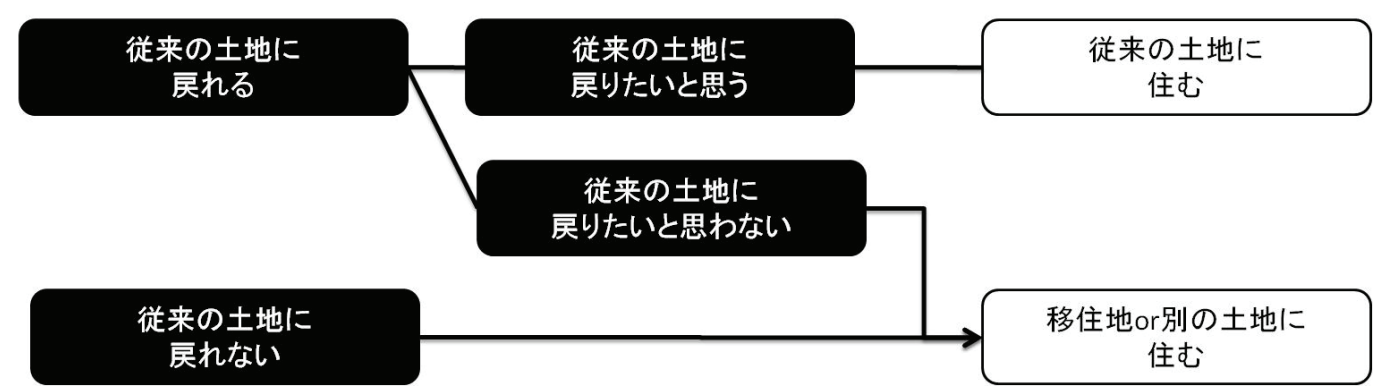

図-13恒久的な居住規制を受けた被災者に対して長期的影響を及ぼす要因（移住地がある場合） 
Calapan市民と同等の土地や家屋資材などの支援は受けら れなかったと予測される。 そのような中，職務中に被災 した場合の支援システムがフィリピン社会に存在するの かどうか，もし存在するならば，本事例ではどのような 支援が実施されたのか，今後調查を進めたい.

\section{9. まとめ}

1994年に発生したミンドロ地震津波災害は, 計78名の 死者を出した.この災害を受け，フィリピン政府は津波 が来襲した地域への居住を規制した．本研究では，居住 規制により移住を余儀なくされた被災者の生活再建や地 域社会の復興状況，労働者や観光客など地域住民でない 人々に対する津波脆弱性の現状，および，それらを支援 した中央・地方政府などの活動の長期的効果の把握を主 目的として，発災から14年が経過した時点で現地調查を 実施した. 以下に結論を示寸.

（1）災害後に居住規制を受けた生存者が，10年を超え る長期的な時間経過の後, 従来の土地に居住するのか, 移住地かまた別の土地に居住するのかについて影響を及 ぼす要因としては, 非心理的な要因と心理的な要因とに 分けて考えることができる（図-13）。今回の事例では, 非心理的な要因として，(1)従来の土地におけるスペース （物理的要因），(2)従来の土地におけるインフラ整備 （住環境的要因），(3)住宅建設コストや仕事の有無（経 済的要因）が挙げられる。これらの条件によっては被災 者は心理的な要因に関わらず，従来の土地には戻れない．

（2）心理的な要因としては，(1)個別の被災経験，(2)居 住地と仕事場へのアクセス, (3)移住先のコミュニティと の関係，(4)土地所有権が挙げられる. これらの条件は, 非心理的要因で従来の土地に戻れる条件であった場合に, 被災者が実際に戻るかどうかを心理的に左右する。

（3）被災した住民を支援した政府などの活動の長期的 効果としては, 住宅再建を含めた移住地開発と高校にお ける防災教育に注目した。 まず，移住地開発としては，

「Food-for-Work」の枠組みに基づく住宅再建がNew Wawa とUbasanの両移住地における住民の定住に効果的 であったと考えられる．また，土地所有者証明書の発行 の有無は, 上述の通り移住地へ移った生存者が Old Wawaへ戻るかどうかに影響している可能性があり，こ れ以上Old Wawaへ戻る住民を増やさないために, New Wawaへの発行を急ぐべきである.

（4）今回の調査で実施されていることが分かった高校 生への防災教育に関しては, 被災から14年が経過した現 在でも被災経験を伝承させることに寄与している可能性 がある.つまり，こうした取組みが単に高校生を対象と
しているのではなく, 高校生を通して家庭をも対象とし ていることで, 家庭内で両親や祖父母㘦子供へと津波 の経験が伝わる場を生み出している可能性があり, 非常 に注目される取組であると言える，さらに，学校での継 続的な防災教育により，知識や訓練を受けた人が毎年社 会に増えていくことになり，長期的に見ると社会全体の 防災に関する住民知識のレベルアップにつながる.

（5）労働者や観光客など地域住民でない人々に対する 津波脆弱性の現状について調查した. その結果, 観光地 においては被災経験の伝承を確実に行うことが困難であ ったことが分かった：それに関連し，リゾート地開発を 行う労働者とリゾート地完成後の観光客への安全性が非 常に脆弱である可能性が明らかになった. 行政への調査 はできていないが，彼らは地方政府の監督下に置かれて いない可能性があり，今回の場合では，労働者の安全性 は雇用主の意識に左右される.

謝辞：（独）国際協力機構（JICA）の山本将史氏，野村 陽子氏には，本調査の前に現地の状況について多くの有 益な情報をいただきました。ここに感謝の意を表させて いただきます，なお，本研究の実施にあたっては，建設 技術研究開発費補助金「日本周辺で発生する津波を対象 とした環太平洋情報ネットワークの開発（研究代表者 : 河田惠昭) 」の補助を得ました.

\section{参考文献}

1) Imamura, F., C. E. Synolakis, E. Gica, V. Titov, E. Listanco and H.J. Lee : Field Survey of the 1994 Mindoro Island, Philippines Tsunami, PAGEOPH, Vol.144, pp.875-890, 1995.

2) PHIVOLCS Quick Response Teams: 15 November 1994 Mindoro Earthquake Preliminary Report of Investigation, PHIVOLCS Special Report No.2, Department of Science and Technology, 1994.

3) 今村文彦 - Edison Gica • Ho Jun Lee - Costas Synolakis • Titov Vasily • Eddie Listanco • Seiichi Kawashima • Delfin Esplanada : 1994 年11月15日フィリピン・ミンドロ島地震津波の現地調査, 津波工学研究報告, 12, pp.19-23, 1995.

4) 奥村与志弘・高橋智幸・越村俊一・原田賢治・鈴木進吾 河田惠昭：インドネシアの災害文化に関する一考察一津波 災害復興状況調査を踏まえて一, 第27回日本自然災害学会 年次学術講演会概要集, pp. 83-84, 2008.

5) 中央防災会議，災害教訓の伝承に関する専門調査会，1896 明治三陸津波報告書, p. 165，2005。

6) 矢守克也 - 横松宗太 - 奥村与志弘 - 阪本真由美 - 河田惠昭 : 2006年2月フィリピン・レイテ島地滑り災害からの生活再建 と地域復興一第2次現地調查の結果に基づいて一京都大学防 災研究所年報，第50号A，pp. 153-160，2007.

（原稿受理2009年6月28日） 


\section{LONG-TERM EFFECTS OF SOCIAL RESPONSES IN THE 1994 MINDORO TSUNAMI}

DISASTER IN ORIENTAL MINDORO, PHILIPPINES

\section{Yoshihiro OKUMURA, Kenji HARADA, Edison GICA, Tomoyuki TAKAHASHI, Shunichi KOSHIMURA, Shingo SUZUKI and Yoshiaki KAWATA}

This study aimes to find out long-term effects of social responses in the 1994 Mindoro tsunami disaster in Oriental Mindoro, Phillipines. In the results, we found out that the resettlement policy toward residents in huge damaged areas by the government was successful so far. Rebuilding houses method "Food for Work" and improvement of infrastructure in the relocation sites were effective against the long-term success of the resettlement policy. In order to continue this success in the future, early issue of land ownership certificate for the residents who have not got ever, and continuance of disaster education in the local high schoole enveloped students' families will be essential. 